University of Nebraska - Lincoln

DigitalCommons@University of Nebraska - Lincoln

1993

\title{
Effect of Calcium Source, Dietary Calcium Concentration, and Gestation Phase on Various Bone Characteristics in Gestating Gilts
}

G. L. Walker

Walnut Grove Products

D. M. Danielson

University of Nebraska

E. R. Peo, Jr.

University of Nebraska-Lincoln

R. F. Mumm

University of Nebraska

Follow this and additional works at: https://digitalcommons.unl.edu/animalscifacpub

Part of the Animal Sciences Commons

Walker, G. L.; Danielson, D. M.; Peo, Jr., E. R.; and Mumm, R. F., "Effect of Calcium Source, Dietary Calcium Concentration, and Gestation Phase on Various Bone Characteristics in Gestating Gilts" (1993). Faculty Papers and Publications in Animal Science. 692.

https://digitalcommons.unl.edu/animalscifacpub/692

This Article is brought to you for free and open access by the Animal Science Department at DigitalCommons@University of Nebraska - Lincoln. It has been accepted for inclusion in Faculty Papers and Publications in Animal Science by an authorized administrator of DigitalCommons@University of Nebraska - Lincoln. 


\title{
Effect of Calcium Source, Dietary Calcium Concentration, and Gestation Phase on Various Bone Characteristics in Gestating Gilts ${ }^{1,2,3}$
}

\author{
G. L. Walker4, D. M. Danielson ${ }^{5,6}$, E. R. Peo, Jr.6, and R. F. Mumm7 \\ West Central Research and Extension Center, University of Nebraska, North Platte 69101
}

ABSTRACT: Sixty gravid crossbred gilts were allotted to a $2 \times 3 \times 2$ factorial arrangement of treatments: two $\mathrm{Ca}$ sources (sun-cured alfalfa meal and $\left.\mathrm{CaCO}_{3}\right)$, three dietary concentrations of $\mathrm{Ca}(50$, 75 , and $100 \%$ of NRC requirements), and two phases of gestation ( 55 and $105 \mathrm{~d}$ ). The objectives were to determine the effect of $\mathrm{Ca}$ source, dietary $\mathrm{Ca}$ concentration, and gestation phase on bone characteristics (bone breaking strength, bone ash percentage, bone density, and bone ash density in the rib, thoracic, and coccygeal bones), to correlate bone responses to determine relative bone activity, and to determine reliability of the coccygeal bones as indicators of $\mathrm{Ca}$ status in the body. At $55 \mathrm{~d}$, rib strength and coccygeal ash content were lower $(P<.01)$ than at $105 \mathrm{~d}$ of gestation. A gestation phase $\times \mathrm{Ca}$ concentration $(P<$ $.05)$ interaction occurred. As $\mathrm{Ca}$ concentration in- creased, thoracic strength and rib ash responded quadratically during each gestation phase, for which at $55 \mathrm{~d}$ a minima and at $105 \mathrm{~d}$ a maxima was produced at $75 \%$ of NRC. A Ca source $\times$ Ca concentration $(P<.05)$ interaction occurred. Gilts fed alfalfa had the lowest rib bone and ash density when fed $75 \%$ of $\mathrm{NRC}$ for $\mathrm{Ca}$, whereas gilts fed $\mathrm{CaCO}_{3}$ were highest at this level of $\mathrm{Ca}$ compared with the other concentrations. Generally, all bones were positively correlated with respect to their response to dietary $\mathrm{Ca}$ concentration. Few negative correlations were observed. At this level of physiological maturity, there was no effect of $\mathrm{Ca}$ source and little effect of gestation phase on the bone variables measured at the dietary $\mathrm{Ca}$ concentrations used in this experiment. The rib and thoracic bones seem to be the most responsive to dietary $\mathrm{Ca}$ concentration.

Key Words: Bone Strength, Bone Ash, Bone Density, Alfalfa Meal, Calcium Carbonate, Pigs

J. Anim. Sci. 1993. 71:3003-3010

\section{Introduction}

For many years, alfalfa meal (AM) has been included in swine diets as a source of nutrients. However, AM is high in $\mathrm{Ca}$ and may pose a problem with balancing diets to an acceptable $\mathrm{Ca}: \mathrm{P}$ ratio. Cromwell et al. (1986) reported the Ca bioavailability

\footnotetext{
1Journal series no. 9181, Univ. of Nebraska Agric. Res. Div.

2The authors gratefully acknowledge G. S. Smith and D. L. Rankins, Dept. of Anim. and Range Sci., New Mexico State Univ. for the oxalate analysis.

${ }^{3}$ The authors thank Brendon Gallagher, Bonnie Johnson, Randy Saner, Beama Sanson, Merle Still, and Joel Wenninghoff for their part in care and feeding of animals and technical assistance in preparing this manuscript.

${ }^{4}$ Present address: Walnut Grove Products, 201 Linn St., Atlantic, IA 50022 .

${ }^{5}$ To whom correspondence should be addressed.

${ }^{6}$ Professor Emeritus, Dept. of Anim. Sci., Univ. of Nebraska, Lincoln.

${ }^{7}$ Professor of Biometry, Univ. of Nebraska, Lincoln.

Received December 9, 1991.

Accepted June 30, 1993.
}

in alfalfa meal to be approximately $22 \%$, but the bioavailability of $\mathrm{Ca}$ in sun-cured $\mathrm{AM}$ is unknown when fed to gravid swine.

During gestation, nutrient requirements change, especially during the second half of the pregnancy (Wrobel and Nagel, 1980; Simesen, 1980). Evaluating the utilization of $\mathrm{Ca}$ during the first compared to the second half of gestation with regard to requirement may lead to dietary adjustments that may improve pig survival and reproductive performance of the sow. Kornegay et al. (1973) reported that the performance of sows fed high $\mathrm{Ca}$ and $\mathrm{P}$ diets was superior to that of those fed lower $\mathrm{Ca}$ and $\mathrm{P}$ diets during gestation. Therefore, source of $\mathrm{Ca}$ may play a role in the performance and longevity of breeding swine.

Bones with a high proportion of trabeculae may be expected to be more sensitive to mineral changes in the diet and more desirable indicators of $\mathrm{Ca}$ status of the body than those with a lower proportion. Therefore, it may be advantageous to use bones such as those from the vertebral column as indicators of $\mathrm{Ca}$ status in more mature animals. Several authors have reported different bones to be most sensitive to dietary 
Table 1. Diet composition

\begin{tabular}{|c|c|c|c|c|c|c|}
\hline \multirow[b]{3}{*}{ Ingredient } & \multicolumn{6}{|c|}{ Diet } \\
\hline & \multicolumn{3}{|c|}{$\begin{array}{c}\mathrm{CaCO}_{3} \\
(\% \mathrm{Ca} \mathrm{NRC})\end{array}$} & \multicolumn{3}{|c|}{$\begin{array}{l}\text { Alfalfa meal } \\
\text { (\% Ca NRC) }\end{array}$} \\
\hline & 50 & 75 & 100 & 50 & 75 & 100 \\
\hline Alfalfa meal & - & - & - & 19.80 & 32.80 & 45.45 \\
\hline Corn & 60.76 & 60.76 & 60.76 & 60.00 & 58.71 & 38.32 \\
\hline Soybean meal & 19.67 & 19.67 & 19.67 & 11.50 & 6.10 & 3.95 \\
\hline Salt & .25 & .25 & .25 & .25 & .25 & .25 \\
\hline Vitamin premix ${ }^{a}$ & .10 & .10 & .10 & .10 & .10 & .10 \\
\hline $\mathrm{NaH}_{2} \mathrm{PO}_{4}$ & .76 & .76 & .76 & .81 & .85 & 1.01 \\
\hline Dry fat ${ }^{b^{4}}$ & - & - & - & .44 & 1.19 & 10.92 \\
\hline $\mathrm{CaCO}_{3}$ & .63 & 1.05 & 1.46 & - & - & - \\
\hline Solka floc ${ }^{c}$ & 6.50 & 10.68 & 13.23 & - & - & - \\
\hline Sand & 11.33 & 6.73 & 3.77 & 7.10 & - & - \\
\hline Total & 100.00 & 100.00 & 100.00 & 100.00 & 100.00 & 100.00 \\
\hline
\end{tabular}

aPremix supplied the following vitamins and minerals per kilogram of diet: 4,405 IU of vitamin A acetate, 440 IU of vitamin $D, 22$ IU of vitamin $\mathrm{E}$ as dl-alpha tocopherol acetate, $1.76 \mathrm{mg}$ of vitamin $\mathrm{K}$ activity from menadione dimethylpyrimidionol bisulfite, $4.4 \mathrm{mg}$ of riboflavin, $26.4 \mathrm{mg}$ of niacin, $440 \mathrm{mg}$ of choline chloride, $15.86 \mathrm{mg}$ of d-pantothenic acid, $238 \mu \mathrm{g}$ of Se; $150 \mathrm{mg}$ of $\mathrm{Zn}\left(\mathrm{ZnSO}_{4}\right), 60 \mathrm{mg}$ of $\mathrm{Mn}(\mathrm{MnO}$ ), 175 $\mathrm{mg}$ of $\mathrm{Fe}\left(\mathrm{FeSO}_{4}\right), 17.5 \mathrm{mg}$ of $\mathrm{Cu}\left(\mathrm{CuSO}_{4}\right), 2 \mathrm{mg}$ of $\mathrm{I}(\mathrm{KI})$.

${ }^{\mathrm{b}}$ Sow Weena dry fat 4-80, Merricks, Middleton, WI.

'Solka floc, James River, Berlin, NH.

Ca status: the vertebrae and ribs (Hendrikson, 1968), the caudal vertebrae (Friedel et al., 1973; Poppe et al., 1973), the femur (Tanksley, 1979), and the humerus, metacarpal, metatarsal, and vertebrae (Crenshaw et al., 1981b). The objectives of this experiment were to determine the effect of $\mathrm{Ca}$ in sun-cured $\mathrm{AM}$ and $\mathrm{CaCO}_{3}$ on various bone characteristics from gilts allowed to gestate for two different time periods (phases), to correlate the response of these bones to each other for relative bone activity when dietary $\mathrm{Ca}$ changes, and to determine whether the coccygeal bones are sensitive indicators of the Ca status of an animal.

\section{Experimental Procedure}

Sixty gravid crossbred gilts (Duroc $\times$ Yorkshire) averaging $120 \mathrm{~kg}$ were used in a completely randomized experimental design in a $2 \times 3 \times 2$ factorial treatment arrangement. There were two sources of $\mathrm{Ca}$ ( $\mathrm{AM}$ and $\mathrm{CaCO}_{3}$ ), three dietary concentrations of $\mathrm{Ca}$ (50,75, and $100 \%$ of NRC [1988] requirements based on grams per animal per day or 7.1, 10.65, and $14.2 \mathrm{~g} /$ $\mathrm{d}$, respectively), and two phases of gestation (55 and $105 \mathrm{~d})$ postbreeding. The 12 treatment combinations were replicated five times using individually fed animals as the experimental unit. Each gilt was fed $2.27 \mathrm{~kg}$ of feed per day divided into two equal meal portions fed in the morning (0700) and afternoon (1700). The orts were collected and weighed after each feeding.

Immediately after breeding, the gilts were assigned to dietary treatments. Animals were maintained in groups of 10 each in earthen pens $(5 \mathrm{~m} \times 23 \mathrm{~m})$ equipped with shelter (open-sided) with access to covered individual gestation feeding stalls capable of ensuring that each gilt received only its portion of the feed at each meal. Each pen was equipped with an automatic waterer located between the shelter and the feeding stalls.

Composition of the experimental diets is shown in Table 1. Chemical composition of AM and the diets, as analyzed, is presented in Table 2. Second cutting of sun-cured alfalfa hay of good quality and color and harvested between 10 to $40 \%$ bloom was stored in a dry barn until needed, then ground through a hammermill using a 9-mm screen. All of the alfalfa used was from the same source. Phosphorus content of the diets was calculated to provide an intake of $11.4 \mathrm{~g} /$ d to meet the NRC (1988) requirement. Dietary lysine was equal to or exceeded the NRC (1988) requirement $(8.2 \mathrm{~g} / \mathrm{d})$. Requirement for lysine was based on total lysine composition, not on available lysine values.

All diets were balanced for NDF fiber content by using solka floc (Solka floc, James River, Berlin, NH) as a purified fiber source. A dried fat product (Sow Weena dry fat 4-80, Merricks, Middleton, WI) was used as an energy source in formulating the diet treatments to be isoenergetic for which all calculations were based on table values (NRC, 1988). Sand was used in various diets as a dietary energy diluent. Vitamin and trace minerals were added to ensure that all diets provided concentrations that met or exceeded NRC (1988) requirements.

At the end of each feeding period ( 55 and $105 \mathrm{~d}$ ), a total of 30 animals were killed (stunned and exsanguinated) following animal care guidelines, and bone specimens were collected. The bones collected were the third rib, the thoracic vertebrae at the third rib, and 
Table 2. Chemical composition of the sun-cured alfalfa meal and gestation diets

\begin{tabular}{|c|c|c|c|c|c|c|c|}
\hline \multirow[b]{3}{*}{ Item } & \multirow[b]{3}{*}{ Alfalfa meal } & \multicolumn{6}{|c|}{ Diet } \\
\hline & & \multicolumn{3}{|c|}{$\mathrm{CaCO}_{3}(\% \mathrm{Ca}$ NRC $)$} & \multicolumn{3}{|c|}{ Alfalfa meal ( $\%$ Ca NRC) } \\
\hline & & 50 & 75 & 100 & 50 & 75 & 100 \\
\hline $\mathrm{DM}, \%$ & 92.05 & 90.94 & 90.72 & 91.16 & 89.88 & 89.69 & 90.33 \\
\hline $\mathrm{CP}, \%$ & 18.60 & 13.95 & 14.13 & 14.67 & 13.26 & 14.29 & 13.70 \\
\hline NDF, \% & 37.59 & 26.10 & 26.14 & 26.69 & 23.56 & 21.80 & 24.62 \\
\hline $\mathrm{Ca}, \%$ & 1.33 & .40 & .56 & .60 & .40 & .48 & .66 \\
\hline $\mathrm{P}, \%$ & .30 & .51 & .49 & .50 & .44 & .50 & .58 \\
\hline Oxalate, $\mathrm{mg} / \mathrm{g}$ & 7.95 & 1.23 & 1,16 & 1.39 & 2.31 & 3.21 & 4.25 \\
\hline $\mathrm{ME}, \mathrm{kcal} / \mathrm{kg}^{\mathrm{a}}$ & 1,320 & 2,684 & 2,684 & 2,684 & 2,684 & 2,684 & 2,684 \\
\hline Lysine, $\%^{\mathrm{a}}$ & .80 & .71 & .71 & .71 & .63 & .58 & .57 \\
\hline
\end{tabular}

${ }^{\mathrm{a} C a l c u l a t e d}$ values.

the first and second coccygeal vertebrae. Response criteria were bone breaking strength, bone ash, bone density, and bone ash density. The bones were prepared by dissecting them from the surrounding tissue using a scalpel and sharp boning knife. The periosteum was removed gently with a short, stiff knife. The dissected bones were frozen $\left(-20^{\circ} \mathrm{C}\right)$ until they were analyzed.

Bone breaking strength of the rib was determined on the prepared bone using the Instron Universal testing apparatus (Model 1123, Instron, Canton, MA) as described by Crenshaw et al. (1981a) and of the thoracic and coccygeal vertebrae as described by Crenshaw et al. (1981b). The bones were thawed to room temperature before analysis.

Percentage of bone ash and bone density was determined on a fat-free bone basis. After strength tests were completed, a cross section $(1.3 \mathrm{~cm})$ of the rib and the entire thoracic and coccygeal were tagged, placed in cheesecloth bags and soaked in methanol for $24 \mathrm{~h}$. The bones were placed in a side-arm Soxhlet extraction apparatus and extracted with anhydrous ethyl ether for $48 \mathrm{~h}$, then allowed to air dry under a hood for $48 \mathrm{~h}$. Dry weight was recorded after drying at $105^{\circ} \mathrm{C}$ overnight. Bone density was determined by calculating grams of bone per unit volume of bone, which was determined by measuring water displacement at a constant temperature in a laboratoryconstructed apparatus capable of measuring volume to the nearest $.05 \mathrm{~mL}$. The bones were sealed with petroleum jelly preventing water from entering the bone, so that true circumferential volume was measured. Volume of the petroleum jelly was determined to be negligible. Percentage of ash was then determined by heating the individual bone cross sections to $700^{\circ} \mathrm{C}$ for $48 \mathrm{~h}$ in a muffle furnace. Bone ash density was calculated from bone density and percentage of ash data as grams of bone ash per unit volume of bone.

Feed ingredients and diet samples were analyzed for DM, CP, NDF, and P according to AOAC (1980) procedures. Calcium content was determined by procedures outlined by Gitelman (1967) as modified by
Moorehead and Briggs (1974) for the rapid flow analyzer (Rapid Flow Analyzer, Alpkem, Clackamas, OR).

\section{Statistical Analysis}

The data were analyzed by least squares ANOVA using the GLM procedure of SAS (1985) for a $2 \times 3 \times$ 2 factorial treatment arrangement in a completely randomized experimental design. The response to graded concentrations of $\mathrm{Ca}$ was assessed using orthogonal comparisons as described by Steel and Torrie (1980). Treatment effects were Ca source, phase of gestation, and dietary Ca concentration. The appropriate interactions were used in the model. Initial weight and gestation day (deviation from termination day; 55 or $105 \mathrm{~d}$, deviation ranged $+3 \mathrm{~d}$ ) were tested as covariables, but were not found to be significant in explaining variation in the responses. Four animals aborted or failed to conceive (no more than one per treatment); thus, the data set was analyzed with missing observations. Apparent abortions or failure to conceive was not related to treatment because these animals were scattered over treatments and not specific to one or two. Correlation coefficients were determined among bones by SAS (1985) procedures.

\section{Results}

There was no effect $(P>.05)$ of $\mathrm{Ca}$ source or dietary $\mathrm{Ca}$ concentration on the bone strength of the rib, thoracic, or coccygeal bones (Table 3 ). However, gilts receiving $\mathrm{AM}$ diets tended to have greater bone strength in the rib than gilts fed $\mathrm{CaCO}_{3}(60.1$ vs 56.6, $\mathrm{kg})$. There was an $(P<.01)$ increase in gestation rib breaking strength and coccygeal ash when gilts were allowed to gestate longer.

Percentage of ash in the thoracic vertebrae and coccygeal bone strength were not influenced $(P>.05)$ by $\mathrm{Ca}$ source, phase of gestation, or dietary $\mathrm{Ca}$ concentration. Percentage of ash within coccygeal 
Table 3. Effect of sun-cured alfalfa meal (AM), dietary calcium concentration (DCa), and gestation phase (GP) on bone breaking strength and ash percentage ${ }^{a}$

\begin{tabular}{|c|c|c|c|c|c|c|}
\hline \multirow[b]{2}{*}{ Item } & \multicolumn{3}{|c|}{ Bone breaking strength, kg } & \multicolumn{3}{|c|}{ Ash, \% } \\
\hline & $\mathrm{Rib}^{\mathrm{b}}$ & $\begin{array}{c}\text { Thoracic } \\
\text { vertebrae }^{c}\end{array}$ & $\begin{array}{l}\text { Coccygeal } \\
\text { vertebrae }\end{array}$ & $\mathrm{Rib}^{\mathrm{c}}$ & $\begin{array}{l}\text { Thoracic } \\
\text { vertebrae }\end{array}$ & $\begin{array}{c}\text { Coccygeal } \\
\text { vertebrae }^{b}\end{array}$ \\
\hline \multicolumn{7}{|c|}{ Ca source } \\
\hline $\mathrm{CaCO}_{3}$ & 56.6 & 27.5 & 19.9 & 61.3 & 59.8 & 59.6 \\
\hline $\mathrm{AM}$ & 60.1 & 28.8 & 18.8 & 61.5 & 59.6 & 59.8 \\
\hline $\mathrm{SE}$ & 1.8 & 1.1 & 1.0 & .2 & .2 & .2 \\
\hline \multicolumn{7}{|l|}{ GP } \\
\hline $55 \mathrm{~d}$ & 55.4 & 27.8 & 19.0 & 61.5 & 59.5 & 59.3 \\
\hline $105 \mathrm{~d}$ & 61.3 & 28.5 & 19.7 & 61.4 & 59.9 & 60.1 \\
\hline SE & 1.8 & 1.1 & 1.0 & .2 & .2 & .2 \\
\hline \multicolumn{7}{|c|}{$\mathrm{DCa}, \% \mathrm{NRC}$} \\
\hline 50 & 55.9 & 25.5 & 17.8 & 61.4 & 59.7 & 59.5 \\
\hline 75 & 58.2 & 29.4 & 19.5 & 61.2 & 59.4 & 59.7 \\
\hline 100 & 61.0 & 29.6 & 20.7 & 61.7 & 60.0 & 59.8 \\
\hline $\mathrm{SE}$ & 2.2 & 1.3 & 1.2 & .2 & .3 & .2 \\
\hline $\mathrm{CV}$ & 17.4 & 22.3 & 27.4 & 1.7 & 2.0 & 1.7 \\
\hline
\end{tabular}

a Least squares means $\pm \mathrm{SE}$.

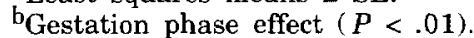

${ }^{\mathrm{c}}$ Gestation phase $\times \mathrm{Ca}$ concentration interaction $(P<.05)$.

bones was not $(P>.05)$ affected by $\mathrm{Ca}$ source or dietary Ca concentration but was greater $(P<.01)$ for gilts gestated $105 \mathrm{~d}$ than for gilts gestated $55 \mathrm{~d}$.

The effect of phase of gestation $\times$ dietary $\mathrm{Ca}$ concentration interaction was significant $(P<.05)$ for rib ash percentage and thoracic breaking strength; whereas gilts gestated for $55 \mathrm{~d}$ responded in a quadratic $(P<.01)$ manner with a slight reduction in rib ash when fed at $75 \%$ of NRC for Ca (Table 4 ). However, in gilts gestated for $105 \mathrm{~d}$ there was no difference $(P>.05)$ in rib ash percentage as the dietary $\mathrm{Ca}$ concentration increased in the diet. The gilts gestated for $105 \mathrm{~d}$ responded quadratically $(P<$ .01 ) in thoracic bone strength, whereas there was no difference in bone strength in gilts gestated $55 \mathrm{~d}$ as dietary $\mathrm{Ca}$ increased.
Thoracic vertebrae did not vary $(P>.05)$ in bone or ash density due to $\mathrm{Ca}$ source, phase of gestation, or dietary $\mathrm{Ca}$ concentration (Table 5). A Ca source $\times$ dietary $\mathrm{Ca}$ concentration interaction was not significant $(P>.05)$ in the thoracic vertebrae for bone and ash density, indicating that bone response to $\mathrm{Ca}$ source was similar as dietary $\mathrm{Ca}$ concentrations increased.

There was a significant $(P<.05) \mathrm{Ca}$ source $\times$ dietary $\mathrm{Ca}$ concentration interaction for bone and ash density in the rib (Table 6). A significant $(P<.05)$ quadratic response was observed within the gilts fed the $\mathrm{CaCO}_{3}$ whereby bone and ash density seemed to peak at $75 \%$ of NRC requirement for $\mathrm{Ca}$. This may be because the amount of $\mathrm{Ca}$ in the feed could have been higher at $75 \%$ of NRC for the AM fed gilts than was

Table 4. Effect of gestation phase (GP) $\times$ dietary calcium concentration (DCa) interaction on thoracic bone breaking strength and rib ash percentage (simple effect) ${ }^{\mathrm{a}, \mathrm{b}}$

\begin{tabular}{|c|c|c|c|c|}
\hline \multirow[b]{3}{*}{$\mathrm{DCa}, \% \mathrm{NRC}$} & \multicolumn{4}{|c|}{ GP } \\
\hline & \multicolumn{2}{|c|}{ Thoracic bone strength, kg } & \multicolumn{2}{|c|}{ Rib ash, $\%$} \\
\hline & $55 \mathrm{~d}$ & $105 \mathrm{~d}$ & $55 \mathrm{~d}^{\mathrm{c}}$ & $105 \mathrm{~d}$ \\
\hline 50 & 27.2 & 23.7 & 61.9 & 60.8 \\
\hline $75^{\mathrm{d}}$ & 25.5 & 33.4 & 60.8 & 61.6 \\
\hline 100 & 30.6 & 28.6 & 61.8 & 61.6 \\
\hline $\mathrm{SE}$ & 1.8 & 1.9 & .3 & .3 \\
\hline
\end{tabular}


Table 5. Effect of sun-cured alfalfa meal (AM), dietary calcium concentration (DCa), and gestation phase (GP) on bone density and bone ash density

\begin{tabular}{|c|c|c|c|c|c|c|}
\hline \multirow[b]{2}{*}{ Item } & \multicolumn{3}{|c|}{ Bone density, $\mathrm{g} / \mathrm{cm}^{3}$} & \multicolumn{3}{|c|}{ Bone ash density, $\mathrm{g}$ of $\mathrm{ash} / \mathrm{cm}^{3}$} \\
\hline & $\operatorname{Rib}^{b}$ & $\begin{array}{l}\text { Thoracic } \\
\text { vertebrae }\end{array}$ & $\begin{array}{l}\text { Coccygeal } \\
\text { vertebrae }\end{array}$ & $\mathrm{Rib}^{\mathrm{b}}$ & $\begin{array}{l}\text { Thoracic } \\
\text { vertebrae }\end{array}$ & $\begin{array}{l}\text { Coccygea } \\
\text { vertebrae }\end{array}$ \\
\hline \multicolumn{7}{|c|}{$\mathrm{Ca}$ source } \\
\hline $\mathrm{CaCO}_{3}$ & .91 & .83 & .77 & .56 & .50 & .46 \\
\hline $\mathrm{AM}$ & .92 & .86 & .78 & .57 & .51 & .47 \\
\hline $\mathrm{SE}$ & .02 & .03 & .01 & .01 & .02 & .01 \\
\hline \multicolumn{7}{|l|}{ GP } \\
\hline $55 \mathrm{~d}$ & .93 & .86 & .77 & .57 & .52 & .46 \\
\hline $105 \mathrm{~d}$ & .90 & .82 & .78 & .55 & .49 & .47 \\
\hline $\mathrm{SE}$ & .02 & .03 & .01 & .01 & .02 & .01 \\
\hline \multicolumn{7}{|c|}{$\mathrm{DCa}, \% \mathrm{NRC}$} \\
\hline 50 & .89 & .83 & .76 & .55 & .50 & .46 \\
\hline 75 & .92 & .83 & .78 & .56 & .49 & .47 \\
\hline 100 & .93 & .88 & .78 & .57 & .53 & .47 \\
\hline $\mathrm{SE}$ & .02 & .04 & .01 & .01 & .02 & .01 \\
\hline $\mathrm{CV}$ & 10.3 & 19.19 & 8.00 & 11.17 & 20.41 & 8.55 \\
\hline
\end{tabular}

a Least squares means.

${ }^{\text {b }}$ Source $\times \mathrm{Ca}$ concentration interaction $(P<.05)$.

anticipated because the dietary analysis indicated higher $\mathrm{Ca}$ in this treatment. Whether these analyzed values are true or were a sampling error is not known, but the higher response at $75 \%$ may indicate that the analyzed values were correct.

When determining correlation coefficients among the bones, it was important to include data reported previously (Walker et al., 1992) on metacarpal and metatarsal bones with the bone data collected herein because these two bones are commonly used in research as indicators of the $\mathrm{Ca}$ status of the body. Therefore, correlations among the five bones were calculated for the response measurements (Table 7). The results indicate positive correlations $(P<.05)$ among all bones for bone strength except between the metatarsal and the rib and between the metatarsal and the coccygeal bones. The metacarpal and metatarsal bones were highly correlated $(\mathrm{r}=.69 ; P<.01)$ as expected. Most of the other significant correlations were lower, but were considered to be important and useful in showing how the response of each bone to treatment relates to the other bones. Significant $(P<$ .05 ) correlation coefficients were observed among all bones for ash percentage (Table 7), except between the metacarpal and the thoracic vertebrae and between the thoracic vertebrae and the coccygeal vertebrae. When the bones were correlated for bone and ash density, the only significant $(P<.05)$ correlations obtained were between the metacarpal and thoracic vertebrae and between the metatarsal and coccygeal bones, which were negative.

\section{Discussion}

The results of bone strength and percentage of ash reported herein agree with data reported previously (Walker et al., 1992) using the metacarpal and

Table 6. Effect of calcium source and dietary calcium concentration (DCa) on rib bone density and ash density (calcium source $x$ dietary calcium concentration interaction simple effects) ${ }^{\mathrm{ab}}$

\begin{tabular}{|c|c|c|c|c|}
\hline \multirow[b]{2}{*}{$\mathrm{DCa}, \% \mathrm{NRC}$} & \multicolumn{2}{|c|}{ Bone density, $\mathrm{g} / \mathrm{cm}^{3}$} & \multicolumn{2}{|c|}{ Bone ash density, $\mathrm{g}$ of $\mathrm{ash} / \mathrm{cm}^{3}$} \\
\hline & $\underset{\text { diet }^{\mathrm{b}}}{\mathrm{CaCO}_{3}}$ & $\begin{array}{c}\text { Alfalfa } \\
\text { meal diet }\end{array}$ & $\underset{\operatorname{diet}^{\mathrm{c}}}{\mathrm{CaCO}_{3}}$ & $\begin{array}{c}\text { Alfalfa } \\
\text { meal diet }\end{array}$ \\
\hline 50 & .84 & .94 & .51 & .58 \\
\hline 75 & .95 & .88 & .59 & .54 \\
\hline 100 & .92 & .93 & .56 & .58 \\
\hline $\mathrm{SE}$ & .03 & .03 & .02 & .02 \\
\hline
\end{tabular}


Table 7. Simple correlation coefficients between all five bones for bone breaking strength, ash percentage, bone density, and ash density

\begin{tabular}{|c|c|c|c|c|c|}
\hline Item & Metacarpal & Metatarsal & $\mathrm{Rib}$ & Thoracic & Coccygeal \\
\hline \multicolumn{6}{|c|}{ Bone breaking strength, $\mathrm{kg}$} \\
\hline Metacarpal & 1.00 & $.69^{* *}$ & $.42^{* *}$ & $.49^{* * *}$ & $.41 * *$ \\
\hline Metatarsal & & 1.00 & .22 & $.34 * *$ & .19 \\
\hline Rib & & & 1.00 & $.40^{* *}$ & $.26^{*}$ \\
\hline Thoracic & & & & 1.00 & $.29 *$ \\
\hline Coccygeal & & & & & 1.00 \\
\hline \multicolumn{6}{|c|}{ Ash percentage, $\%$} \\
\hline Metacarpal & 1.00 & $.72^{* *}$ & $.39 * *$ & .20 & $.29^{*}$ \\
\hline Metatarsal & & 1.00 & $.41 * *$ & $.27 *$ & $.31^{*}$ \\
\hline $\mathrm{Rib}$ & & & 1.00 & $.42^{* *}$ & $.30^{*}$ \\
\hline Thoracic & & & & 1.00 & .24 \\
\hline Coccygeal & & & & & 1.00 \\
\hline \multicolumn{6}{|c|}{ Bone density, $\mathrm{g} / \mathrm{cm}^{3}$} \\
\hline Metacarpal & 1.00 & .13 & -.08 & $-.31 *$ & -.01 \\
\hline Metatarsal & & 1.00 & -.22 & -.12 & $-.33^{* * *}$ \\
\hline Rib & & & 1.00 & .12 & .06 \\
\hline Thoracic & & & & 1.00 & .23 \\
\hline Coccygeal & & & & & 1.00 \\
\hline \multicolumn{6}{|c|}{ Bone ash density, $\mathrm{g}$ of $\mathrm{ash} / \mathrm{cm}^{3}$} \\
\hline Metacarpal & 1.00 & .11 & -.10 & -.05 & .07 \\
\hline Metatarsal & & 1.00 & -.22 & -.12 & $-.32 *$ \\
\hline $\operatorname{Rib}$ & & & 1,00 & .15 & .09 \\
\hline Thoracic & & & & 1.00 & .26 \\
\hline Coccygeal & & & & & 1.00 \\
\hline
\end{tabular}

metatarsal bones; no differences between these two $\mathrm{Ca}$ sources were found. The results indicate that $\mathrm{Ca}$ in $\mathrm{AM}$ was as well utilized as that found in $\mathrm{CaCO}_{3}$, but because the response was not linear to dietary $\mathrm{Ca}$ concentration in the rib, thoracic, and coccygeal bones, it seems that these bones are not as responsive as the metacarpal and metatarsal bones. However, the significant $\mathrm{Ca}$ source $\times \mathrm{Ca}$ concentration interaction for bone and ash density for the rib indicated different response slopes for the curves of the Ca sources; but the interaction for $\mathrm{Ca}$ source $\times \mathrm{Ca}$ concentration that was linear only approached significance $(P<.15)$. The results reported herein favorably agree with those of Ward et al. (1984), who reported Ca availability of alfalfa meal to be 79 to $94 \%$ when fed to chicks. Hintz et al. (1984) reported similar results in ponies where true availability of $\mathrm{Ca}$ in alfalfa hay was estimated to be $80.1 \%$. However, Cromwell et al. (1986) showed that Ca bioavailability in alfalfa meal fed to growing pigs was approximately $22 \%$. The key difference is in age and maturity of animals used herein compared with those used by Cromwell et al. (1986).

Changes in bone characteristics have been used as sensitive methods for evaluating the Ca status of the animal (Hayes et al., 1979; Crenshaw et al., 1981a; Greger, 1988). However, some bones are more sensitive than others to dietary changes in $\mathrm{Ca}$. There are two types of bone tissue: 1) cortical bone that forms the compact outer shell of all bones, most of which is found in the shaft of the long bones, and 2) trabecular bone composed of a connecting network of bony plates (trabeculae). Trabecular bone is found primarily in the vertebral column, pelvis, and at the end of the long bones (Niewoehner, 1988). In young growing pigs, Crenshaw et al. (1981b) reported that all the bones they studied responded positively to increased dietary concentrations of $\mathrm{Ca}$ and $\mathrm{P}$. However, these authors reported that in older pigs the humerus, third and fourth metacarpal, third metatarsal, and thoracic vertebrae were the only bones found to be responsive to increased dietary $\mathrm{Ca}$ and $\mathrm{P}$. The present data differ; the rib showed only a slight increase in bone and ash density to increased dietary $\mathrm{Ca}$ concentration.

The thoracic vertebrae and rib bones tended to increase in strength as the dietary $\mathrm{Ca}$ concentrations increased in the diet, but differences were not significant $(P>.05)$. This may have been due to the high standard error and coefficient of variation observed for these criteria. These results agree in part with those of Hendrikson (1968), who suggested the vertebrae and rib bones to be most responsive to changes in the dietary $\mathrm{Ca}$ concentrations. However, when considering the response of ash percentage and the variations occurring around the data points, it is observed that the bones were not responding very well to treatment or these animals were able to adapt to increase $\mathrm{Ca}$ absorption in a deficient state. Fox et al. (1978) reported that pigs have the ability to increase the efficiency of $\mathrm{Ca}$ absorption in the event a deficiency occurs. The mechanism that allows for this 
compensation showed that renal production of 1 , $25-(\mathrm{OH})_{2} \mathrm{D}_{3}$ from 25-hydroxy-vitamin $\mathrm{D}_{3}$ is increased when the diet is low in Ca because of an increase in parathyroid hormone (PTH) secretion, which is stimulated by lowering plasma $\mathrm{Ca}$ concentrations. There is a corresponding increase in $1,25-(\mathrm{OH})_{2} \mathrm{D}_{3}$ dependent $\mathrm{Ca}$ binding protein in the small intestine when diets are low in $\mathrm{Ca}$ (Freund and Bonner, 1975). These mechanisms in turn act to stimulate $\mathrm{Ca}$ absorption from the gut, to increase the release of $\mathrm{Ca}$ from bone, and to increase $\mathrm{Ca}$ reabsorption from the kidney. Therefore, the endocrine system seems to compensate for deficient $\mathrm{Ca}$ concentrations occurring in the lumen of the small intestines. Previous research has demonstrated that vitamin $\mathrm{D}_{3}$ synthesis varies inversely with $\mathrm{Ca}$ intake, as does the duodenal content of vitamin $\mathrm{D}_{3}$-dependent $\mathrm{Ca}$ binding protein (Freund and Bonner, 1975). These researchers also demonstrated that the reason for increased PTH for stimulating the conversion of vitamin $\mathrm{D}$ metabolites to the active state and, thus, an increase in Ca binding protein was the result of low serum $\mathrm{Ca}$, which cues the parathyroid to increase secretion of the PTH.

Bone densities tended to respond as expected with numerical increases with increased $\mathrm{Ca}$ in the diet. Shupe et al. (1988) found a substantial increase in bone density when cows were fed various levels of $P$ during a 10-yr period when $\mathrm{P}$ was increased in the diet, indicating that density is related to mineral status of the diet. The duration of our study may not have been long enough to show a significant influence of treatment effects on bone density. This may be true partially because the animals were maintained on a high plane of $\mathrm{Ca}$ nutrition before the initiation of the study and that these gilts were approaching physiological maturity at which point bone metabolism would be less than that of the actively growing bones of younger animals.

The effect of $\mathrm{Ca}$ source $\times$ dietary $\mathrm{Ca}$ concentrations interaction in rib bones for bone and ash density was significant $(P<.05)$, indicating that these indicators may be more sensitive than bone strength or percent ash.

The correlation coefficients give an indication of how the bones are related in their response to treatment. The correlation between the metatarsal and coccygeal bones indicate that coccygeal bones may be a possible alternative tissue to use in large animals as a response criterion for mineral status, even though in this study the response of the coccygeal vertebrae to the dietary $\mathrm{Ca}$ concentrations used herein was not significant $(P>.05)$. In cases in which the bones are more active in growth or resorption, they may have merit. Vertebral bones positioned more anterior in the body may not be used as Ca resorption sites as much as are those from the lumbar region, because posterior paralysis ("downer") conditions usually occur in the lumbar region. This condition is due to decalcification of these bones to meet the $\mathrm{Ca}$ requirements during increased physiological demands (Whitehair and Miller, 1975) such as lactation. Perhaps other bones from different locations in the vertebral column should have been collected for better sensitivity or for an indication of which region of the column is most sensitive to mineral changes in the diet.

The effect of phase of gestation on bone characteristics is not clear because the results varied among different bones. Of the bones evaluated, it seems that the rib bones and thoracic vertebrae are the most responsive to dietary changes in $\mathrm{Ca}$. In future studies, as suggested by others, removal of a portion of the tail to obtain coccygeal bones may be valuable in estimating $\mathrm{Ca}$ status of the animal.

The inclusion of fat in the AM diets to equalize energy may or may not have played a role in $\mathrm{Ca}$ absorption. Although fat is generally expected to reduce $\mathrm{Ca}$ absorption because of the formation of insoluble soaps (Tillman and Brethour, 1958; Grainger et al., 1961; Johnson et al., 1956), in this experiment this may not be the case. Newman et al. (1967) in experiments with "weaning" pigs fed diets with $10 \%$ tallow, which is similar to the diets fed herein, found no effect on $\mathrm{Ca}$ absorption; whereas Jordan and Weatherup (1978) found that pigs fed various fat levels (1.6 to $43.9 \%$ ) actually showed an improvement in $\mathrm{Ca}$ absorption at higher fat levels.

These data indicate that animals that are more mature are less likely to develop a deficient status in the bone because of the capacity to adjust $\mathrm{Ca}$ absorption in the hind gut to meet the requirement at least after just one parity. One explanation may be that there is greater hind gut fermentation in swine near maturity allowing greater breakdown of the oxalates and phytates when gilts are fed diets containing alfalfa, thus producing more $\mathrm{Ca}$ available for absorption. Calcium absorption in the colon of the rat was increased by the presence of $1,25-(\mathrm{OH})_{2} \mathrm{D}_{3}$ when Ca-deficient diets were fed (Favus et al., 1980). They found that low $\mathrm{Ca}$ diets stimulated additional uptake of $\mathrm{Ca}$ by everted gut sac segments of the ascending and descending colon, but not the transverse colon, thus supporting the idea that $\mathrm{Ca}$ absorption may be increased significantly from this area when the diet is low in $\mathrm{Ca}$. When performing $\mathrm{Ca}$ balance studies, another factor that may play an important role in the mature animal is the increased surface area of the gut to nutrient availability compared with that in the smaller growing animal. Thus, there are more sites for absorption and more chances of meeting the requirement.

The physiological changes that occur when $\mathrm{Ca}$ is deficient may also occur when the $\mathrm{Ca}$ need is increased by pregnancy and lactation. Wrobel and Nagel (1980) found that intestinal $\mathrm{Ca}$ transport in the rat started to increase during the 2nd wk of pregnancy and peaked at parturition, with a subsequent decline during late lactation. The length of the jejunum, which is capable of active transport, in- 
creased so that the duodenum and the jejunum had a similar rate of $\mathrm{Ca}$ absorption. Kostial et al. (1969) demonstrated with low-Ca diets that both active and diffusional $\mathrm{Ca}$ transport doubled with a total increase in intestinal transfer of $340 \%$. Armbrecht et al. (1980) found that $\mathrm{Ca}$ binding protein increased in the intestine during pregnancy in the rat, thus increasing the $\mathrm{Ca}$ transport system. Lund and Selnes (1979) showed that increased prolactin during late pregnancy is correlated with an increase in $1,25-(\mathrm{OH})_{2} \mathrm{D}_{3}$, which is associated with increased $\mathrm{Ca}$ binding protein and thus increased $\mathrm{Ca}$ absorption. When considering these physiological capabilities, it becomes evident that many factors affect the $\mathrm{Ca}$ status of the gestating animal, making it difficult to create a deficient state so that bioavailability studies may be conducted. The physiological state and the maturity of the animal influence $\mathrm{Ca}$ absorption as much as do the conditions occurring in the Ca source itself. The results herein indicate that when $\mathrm{Ca}$ is $50 \%$ below the requirement, these animals had the ability to adapt to meet the requirement.

\section{Implications}

There was little difference between sun-cured alfalfa and calcium carbonate on Ca status in gravid gilts. The rib bone and thoracic vertebrae were the most sensitive to dietary $\mathrm{Ca}$ changes in these animals. The bones of mature animals were less prone than those of young animals to deficiency status.

\section{Literature Cited}

AOAC. 1980. Official Methods of Analysis (13th Ed.). Association of Official Analytical Chemists, Washington, DC.

Armbrecht, H. J., T. V. Zenger, C. J. Gross, and B. B. Davis. 1980. Adaptation to dietary calcium and phosphorous restriction changes with age in the rat. Am. J. Physiol. 239:E322.

Crenshaw, T. D., E. R. Peo, Jr., A. J. Lewis, and B. D. Moser. 1981 a. Bone strength as a trait for assessing mineralization in swine: A critical review of techniques involved. J. Anim. Sci. 53:827.

Crenshaw, T. D., E. R. Peo, Jr., A. J. Lewis, B. D. Moser, and D. Olson. 1981b. Influence of age, sex and calcium and phosphorus levels on the mechanical properties of various bones in swine. J. Anim. Sci. 52:1319.

Cromwell, G. L., T. S. Stahly, and H. J. Monegue. 1986. Calcium availability found low in alfalfa meal fed to pigs. Feedstuffs $58(27): 14$.

Favus, M. I., S. C. Kathpalia, F. L. Coe, and A. E. Mond. 1980. Effects of diet calcium and 1,25 dihydroxy-vitamin D on colon active transport. Am. J. Physiol. 238:675.

Fox, J., D. W. Pickard, A. D. Care, and T. M. Murray. 1978. Effect of low phosphorus diets on intestinal calcium absorption and the concentration of calcium binding protein in intact and parathyroidectomized pigs. J. Endocrinol. 78:379.

Freund, T., and F. Bonner. 1975. Regulation of intestinal calciumbinding protein by calcium in the rat. Am. J. Physiol. 228:861.

Friedel, K., M. Gabel, and S. Poppe. 1973. Studies for estimating the calcium and phosphorus supply of pigs. 2. Studies on sows. Arch. Tierz. 23(8):701.

Gitelman, H. J. 1967. An improved automated procedure for the determination of calcium in biochemical specimen. Anal. Biochem. 18:521.
Grainger, R. B., M. C. Bell, J. W. Stroud, and F. H. Baker. 1961. Effect of various cations and corn oil on crude cellulose digestibility by sheep. J. Anim. Sci. 20:319.

Greger, J. L, 1988. Calcium bioavailability. Cereal Foods World $33(9): 796$

Hayes, S. H., G. L. Cromwell, T. S. Stahly, and T. H. Johnson. 1979. Availability of phosphorus in corn, wheat and barley for the chick. J. Anim. Sci. 49:992.

Hendrikson, P. A. 1968. Periodontal disease and calcium deficiency. Acta Odontol. Scand. 26(Suppl. 50):1.

Hintz, H. F., H. F. Schryver, J. Doty, C. Lakin, and R. A. Zimmerman. 1984. Oxalic acid content of alfalfa hays and its influence on the availability of calcium, phosphorus and magnesium to ponies. J. Anim. Sci. 58:939.

Johnson, D., K. L. Kolge, J. E. Rousseau, R. Teichman, and H. D. Eaton. 1956. The addition of inedible tallow to a calf starter fed to Holstein calves. J. Dairy Sci. 39:1268.

Jordan, J. W., and S.T.C. Weatherup. 1978. The effect of dietary fat levels on the absorption and retention of calcium, phosphorus, and magnesium by early weaned pigs. Rec. of Agric. Res. 29-34. Queen's University of Belfast.

Kornegay, E. T., H. R. Thomas, and T. N. Meacham. 1973. Evaluation of dietary calcium and phosphorus for reproducing sows housed in total confinement on concrete or in dirt lots. J. Anim. Sci. 37:493.

Kostial, K., N. Gruden, and A. Durakovic. 1969. Intestinal absorption of calcium- 47 and strontium- 85 in lactating rats. Calcif. Tissue Res. 4:13.

Lund, B., and A. Selnes. 1979. Plasma 1,25-dihydroxy-vitamin D levels in pregnancy and lactation. Acta Endocrinol. 92:330.

Moorehead, W. R., and H. G. Briggs. 1974. 2-amino-2-methyl1-propanol as the alkalizing agent in an improved continuousflow cresolphthalein complexon procedure for calcium in serum. Clin. Chem. 20:1458.

Newman, C. W., D. M. Thrasher, S. L. Hansard, A. M. Mullins, and R. F. Boulware. 1967. Effects of tallow in swine rations on utilization of calcium and phosphorus. J. Anim. Sci. 26:479.

Niewoehner, C. 1988. Calcium and osteoporosis. Cereal Foods World. 33(9):784.

NRC. 1988. Nutrient Requirements of Swine (9th Ed.). National Academy Press, Washington, DC.

Poppe, S., K. Fiedel, and M. Gabel. 1973. Studies for estimating the calcium and phosphorus supply of pigs. 1. Studies on fattening pigs. Arch. Tierz, 23(8):685.

SAS. 1985. SAS User's Guide: Statistics. SAS Int. Inc., Cary, NC.

Shupe, J. L., J. E. Butcher, J. W. Call, A. E. Olson, and J. T. Blake 1988. Clinical signs and bone changes associated with phosphorus deficiency in beef cattle. Am. J. Vet. Res. 49:1629.

Simesen, M. G. 1980. Calcium, phosphorus and magnesium metabolism. In: Jiro J. Kaneko (Ed.) Clinical Biochemistry of Domestic Animals. pp 576-612. Academic Press, New York.

Steel, R.G.D., and J. H. Torrie. 1980. Principles and Procedures of Statistics: A Biometrical Approach (2nd Ed.). McGraw-Hill Book Co., New York.

Tanksley, T. D. 1979. Nutrition and Management of Breeding Herd. Proc. Alabama Pork Ind. Conf., Auburn.

Tillman, A. D., and J. R. Brethour. 1958. The effect of corn oil upon the metabolism of calcium and phosphorus by sheep. J. Anim. Sci. 17:782.

Walker, G. L., D. M. Danielson, E. R. Peo, Jr., and R. F. Mumm. 1992. Bioavailability of calcium in sun-cured alfalfa meal and effect of dietary calcium concentration on bone and plasma characteristics during two phases of gestation in gravid gilts. J. Anim. Sci. 71:124.

Ward, G., L. Harbers, A. Kahrs, and A. Dayton. 1984. Availability of calcium from alfalfa for chicks. Poult. Sci. 63:82.

Whitehair, C. K., and E. R. Miller. 1975. Nutritional Deficiencies. In: H. W. Dunne and A. D. Leman (Ed.) Diseases of Swine (14th Ed.). pp 1092-1093. The Iowa State University Press, Ames.

Wrobel, J., and G. Nagel. 1980. Diurnal variations of active calcium transport in the intestine of the pregnant and lactating rat. Biomedicine 33:143. 